DOI https://doi.org/10.18551/rjoas.2018-12.29

\title{
TRUE-TO-TYPENESS STATUS OF CERTIFIED PARENT AND COMMERCIAL CITRUS PLANTS
}

\author{
Hardiyanto \\ Indonesian Center for Horticulture Research and Development, Indonesia \\ Devy Nirmala Friyanti ${ }^{\star}$, Yulianti Farida \\ Indonesian Citrus and Subtropical Fruit Research Institute, Indonesia
}

*E-mail: nfdevy@gmail.com

\begin{abstract}
In 1987 Indonesia started to produce virus-free (VF) mother plants by using shoot-tip-grafting (STG) technique. To date, the propagation and distribution of VF plants are made through several stages of certified protected parent plants, i.e. Foundation Blocks (FB) and Budwood Multiplication Blocks (BMB). $\mathrm{FB}, \mathrm{BMB}$, and commercial farmer plants are derived from propagated of STG, FB, and BMB trees, respectively. The research was done in June December 2017 at Plant Breeding Laboratory, Indonesian Citrus and Subtropical Fruit Research Institut (ICSFRI). Eighty-three and 66 samples were derived from parent and seedling and production, respectively. The cultivars used were Mandarin Batu 55, SoE, Terigas, and Tangerine Pontianak, and Banjar collected from five provinces. As a control for every cultivar, a single collection mother tree was used. The method used was based on the similarities between DNA band plant samples and control produced both by five ISSR and retrotransposon markers. The purpose of this research was to evaluate genetic deviations of parent virus-free and commercial citrus plants derived from five provinces. The results indicated that 5.1 and $8.2 \%$ were off type plants, with the degree of genetic deviation was among $4.9-36.4 \%$ and $3.7-23.1 \%$ for parent and commercial samples, respectively. For parent plants of cv. Batu 55 and Pontianak were all on type, but not for others samples. This result indicated that management both at screen house and field needs to be done carefully, so that the quality of the commercial seeds and plants produced remain the same as the parent.
\end{abstract}

\section{KEY WORDS}

Budwood multiplication block, cultivar, citrus, DNA, foundation block, true to type, virus.

The success of citrus farming is determined by various factors, including the quality of planted seeds, maintenance, and the efficiency of the existing supply chain. The high quality citrus seeds are defined as free-systemic pathogenic plants such as Citrus Vein Phloem Degeneration (CVPD), Citrus Tristeza Virus (CTV), Citrus Vein enation virus (CVEV), Citrus Exocortis Viroid (CEV), and Citrus Psorosis Virus (CPsV); are guaranteed of the purity of both their scion and rootstock; and the stages of the production process are in accordance with the regulation of seed supervision and certification, so that the plants produced are virus-free (VF) and true-to-type to their parents (Devy et al., 2015).

In accordance with the national standard of virus-free citrus plant-making process, the VF mother plants are produced by using shoot-tip-grafting (STG) technique which become the source materials for Foundation Blocks (FB). Then the BF plants are used to make Budwood Multiplication Blocks (BMB). To prevent re-infection in the field, the BF and BMB parent plants are managed in an insect proof screen house. In order to ensure the health and quality of the budwood produced, the BMB plant is only allowed to be harvested for three consecutive years.

The need for availability of high-quality plants in large quantities requires a good planning. Information about the accurate BMB plant conditions would determine the next VF plant production process. During the 2009-2014 period, IAARD through ICSFRI had 
produced and distributed 4,437 and 27,647 plants of $B F$ and $B M B$, respectively to 26 provinces (Harwanto and Utomo 2014). If each BMB plant produced 200 buds or seedling plants, then there were at least $5,529,400 \mathrm{VF}$ citrus plants produced by farmers that required planting area of about 11,058 hectares.

To produce high-quality citrus plants, the purity of the scion and rootstock must be guaranteed, the greater the degree of purity, the higher the similarity with their parent. If there is a genetic deviation in the certified parent and seedling plants, it will cause a difference in the productivity and quality of the fruit produced. Various methods of morphological, physiological, cytological, isozyme and molecular observation are used to detect genetic stability of plants. The development of molecular methods completes the weaknesses of conventional breeding in the identification process (JinPing et al., 2009). This method has a higher accuracy for the identification of plant genetic stability (Bhattacharyya et al., 2014; Carra et al., 2012; Saha et al., 2014).

One of the tools for identifying diversity in plants is a molecular marker based on repetitive sequences. Repeated sequences are spread along the genome as a dominant element of the nuclear-genome and organelle (Alzohairy et al., 2014; Kalendar et al., 1999). Two popular types of repeat sequences are inter-simple repeat sequence (ISSR) and retrotransposon. The ISSR uses short sequences of oligonucleotides, 2-6 bases, repeated in a series of sequences, simple repeat sequences, spread throughout the eukaryotic genome (Tautz and Renz, 1984), which are present both within the gene intron region and non-coding genes (Scarano et al., 2002a) so that the number of repetitions along the genome is high. As a primer, ISSR markers are easy to do, simple, fast, consistent, require low DNA print quantity (10-30 bp), able to distinguish individuals with close relationship and do not require much information to design primers (Zietkiewicz et al., 1994). This marker has been successfully employed for evaluating the genetic diversity (Uzun et al, 2009; Kumar et al, 2010; Marak and Laskar, 2010; Biswas et al., 2010; Munankarmi et al., 2018). According to Martasari et al. (2012), the ISSR procedure is an informative and suitable approach to the examination of the molecular polymorphism and the phylogenic relationships in the Indonesian Siam cultivars. Whereas retrotransposon is a repetitive primary class of DNA, which consists of $40-60 \%$ of the genome in plants, dominant with a long, clear base arrangement, a stable sequence, and insertion of new polymorphisms produced by the active side by replication (Hirochika, 1995; Weising et al., 2005. The purpose of this research was to evaluate genetic deviations of certified parent virus-free and commercial plants derived from five provinces when they compared to the mother plants.

\section{MATERIALS AND METHODS OF RESEARCH}

The research was conducted from June to December 2017 at the Breeding Laboratory of ICiSFRI. The samples were young citrus leaves of five cultivars namely Mandarin Batu 55, M. SoE, M. Terigas, Tangerine Pontianak, and T. Banjar. They were collected from five provinces, i.e. East Java (KP. Punten, KP. Tlekung, KP. Kliran, Banyuwangi, Nongkojajar/Pasuruan, Tumpang/Dist. Malang, and Batu City, West Kalimantan (BBI Anjungan, KP. Monterado, Citrus Center, and Diperta Kab. Sambas), South Kalimantan (farmer in Tapin, UPBH Labuhan-Tapin, BBH Dahirang-Batola, UPBH Sangkal-Banjar Baru), Riau (Kabar District), and NTT (Nonbes BBI, Diperta Denali, SoE District, and Baituka). The total samples analyzed from five citrus varieties were 92 and 66 samples derived from certified parent (BF and BMB) and seedling/production, respectively. The BF samples were taken from each plant, while others were composite from 10 plants. As a control for every cultivar, sample from mother plant that is a duplicate of VF plant produced by using shoot-tipgrafting (STG) technique was used. The types of varieties, seed classes, and sampling locations are listed in Table 1.

The level of genetic similarity of citrus leaf samples was analyzed using 5 ISSR markers, namely (AG) 8YT, (GA) 8YG, BDB (TCC) 5, (AC) 8YG and (GT) 8YC and 5 retrotransposon markers (LTR1, LTR2, LTR3, LTR4, and LT5).

Extraction, isolation and quantification of DNA: 
They were carried out by following the CTAB method (Doyle and Doyle, 1990). The samples were managed following the metode of bulk segregant analysis (BSA). A total of $100 \mathrm{mgs}$ of leaf samples were ground in $1.5 \mathrm{ml}$ of extraction buffer ( $2 \%$ CTAB, $20 \mathrm{mM}$ EDTA, $100 \mathrm{mM}$ Tris $\mathrm{HCl}, 1.4 \mathrm{M} \mathrm{NaCl}, 2 \%$ PVP and $0.2 \%$ mercapto-ethanol). Scour mixture and extraction buffer were incubated at $65^{\circ} \mathrm{C}$ for 30 minutes. The mixture was allowed to stand for 2 minutes at room temperature then added with Na-acetate $(1 / 10 \times$ volume $)$ and $1 \mathrm{ml}$ CHISAM (chloroform: isoamil-alcohol 24: 1).

Table 1 - Cultivar, Total and origin of samples for DNA diversity analysis

\begin{tabular}{|c|c|c|c|}
\hline Cultivar & Sample of & Total & Derived from \\
\hline \multirow{4}{*}{ M. Batu55 } & $\mathrm{BF}$ & 1 & KP. Punten \\
\hline & $\mathrm{BMB}$ & 6 & KP. Punten, KP. Tlekung \\
\hline & Seedling & - & - \\
\hline & Prod plant & 15 & Batu, Dist. Malang \\
\hline \multirow{4}{*}{ M. SoE } & $\mathrm{BF}$ & 3 & BBI Nonbes, BBI Riau \\
\hline & BMB & 20 & KP. Punten, BBI Nonbes, Diperta Denali, SoE \& Baituka Farmers \\
\hline & Seedling & 8 & Diperta Denali, SoE Farmers \\
\hline & Prod plant & - & - \\
\hline \multirow{4}{*}{ M. Terigas } & $\mathrm{BF}$ & 2 & KP. Punten, BBI Anjungan \\
\hline & BMB & 11 & $\begin{array}{c}\text { KP. Punten, Banyuwangi farmers, BBI Anjungan, KP. Monterado, Dist. } \\
\text { Sambas }\end{array}$ \\
\hline & Seedling & 4 & BBI Anjungan, Citrus Center \\
\hline & Prod plant & 9 & Citrus Center, Tumpang, KP. Kliran \\
\hline \multirow{4}{*}{ T. Pontianak } & $\mathrm{BF}$ & 3 & KP. Punten, BBI Anjungan \\
\hline & BMB & 16 & $\begin{array}{c}\text { KP. Punten, Banyuwangi farmers, BBI Anjungan, KP. Monterado, Dist. } \\
\text { Sambas }\end{array}$ \\
\hline & Seedling & 11 & Banyuwangi, BBI Anjungan, BBI Nongkojajar, Kab. Sambas farmer \\
\hline & Prod plant & 19 & $\begin{array}{c}\text { Banyuwang \& Dist. Sambas farmers, Citrus Center, Tumpang, Ponco } \\
\text { Kusumo, \& Karang Anyar }\end{array}$ \\
\hline \multirow{4}{*}{ T. Banjar } & $\mathrm{BF}$ & 4 & KP. Punten, UPBH Labuhan, BBH Dahirang, UPBH Sangkal \\
\hline & BMB & 26 & KP. Punten, Riau \& Dist Tapin farmers, BBH Dahirang, UPBH Sangkal \\
\hline & Seedling & - & 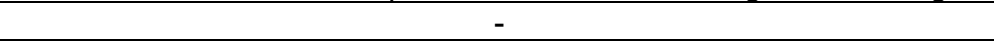 \\
\hline & Prod plant & - & - \\
\hline \multicolumn{2}{|c|}{ Total of samples } & 158 & - \\
\hline
\end{tabular}

Separation of the mixture was carried out by centrifugation for 10 minutes at a 12,000 rpm speed. The supernatant formed is taken and transferred to a new centrifuge tube then added with Na-acetate $(1 / 10 \times$ volume), followed by the addition of isopropanol $(0.6 \mathrm{x}$ volume) for DNA precipitation. This mixture was centrifuged at a speed of $12,000 \mathrm{rpm}$ for 10 minutes to precipitate DNA.

The deposit DNA was washed with $70 \%$ ethanol, dried and reconstituted with $500 \mu \mathrm{TE}$ buffer. The DNA was added with $1 \mu$ RNAse and incubated at $37^{\circ} \mathrm{C}$ for 30 minutes; and the supernatant was collected after centrifugation for 10 minutes at a speed of $12,000 \mathrm{rpm}$, supplemented with $\mathrm{Na}$-acetate (1/10 $\mathrm{x}$ volume) and absolute ethanol $(2.5 \mathrm{x}$ volume) for DNA precipitation. DNA precipitation is assisted by centrifugation at a speed of $12,000 \mathrm{rpm}$ for 10 minutes. The deposit of DNA is washed with $70 \%$ ethanol, dried and reconstituted with 50 100 TE buffer.

Amplification and DNA separation with 10 ISSR and retrotransposon markers:

$50 \mathrm{ng}$ of DNA and $0.5 \mathrm{pmol}$ of primer are put into PCR buffer (Dream Tag Green-PCR Master Mix, Thermo Scientific). Amplification was done with a PCR (Thermocycler-Biometra) machine. The amplification of the ISSR marker begins with a denaturation cycle of $94^{\circ} \mathrm{C}$ for 3 minutes, followed by 28 denaturation cycles of $94^{\circ} \mathrm{C}$ for 45 seconds, annealing temperature of $53^{\circ} \mathrm{C}$ for 1 minute, with an extension of $72^{\circ} \mathrm{C}$ for 2 minutes. The PCR cycle for the ISSR marker was ended with 1 final extension cycle at $72^{\circ} \mathrm{C}$ for 10 minutes (Scarano et al., 2002b).

Amplification with retrotransposon markers begins with a denaturation cycle of $94^{\circ} \mathrm{C}$ for 5 minutes, followed by 30 denaturation cycles of $94^{\circ} \mathrm{C}$ for 1 minute, annealing at $45^{\circ} \mathrm{C}$ for 2 
minutes, extension of $72^{\circ} \mathrm{C}$ for 3 minutes and ending with one final extension cycle at $72^{\circ} \mathrm{C}$ for 10 minutes with a cooling temperature of $4^{\circ} \mathrm{C}$ (Crowley, 2011).

Separation of DNA bands from amplification was done by electrophoresis method on agarose gel (Vivantis, \# PC0701) 2.5\% containing ethidium bromide (10 mg / I) in a solution of $0.5 \times$ TBE for 60 minutes at a current strength of 100 volts. DNA bands detection was done with a biodocumentation system (BioDoc -Biorad).

Variables observed:

Observations were made on the DNA band profile produced by electrophoresis. Addition or loss of DNA bands compared to the control indicated the presence of an off-type.

Data analysis:

DNA profile translates into binary data based on the presence of a band (1) and no DNA band (0). DNA bands from the results of marker molecular analysis are considered as 1 character representing 1 DNA locus. DNA bands with the same migration rate are assumed to be homologous loci. Binary data is used to construct a similarity matrix (qualitative data). The percentage of diversity is calculated using the DARWin5 (Dissimilaritys Analysis Representation for Windows) software. The percentage of diversity indicates the presence of off-type.

\section{RESULTS AND DISCUSSION}

Certified parent plants of BF and BMB. From the $92 \mathrm{BF}$ and BMB samples, 8 of BMB ones $(8,7 \%)$ were off type, namely Mandarin SoE, Mandarin Terigas and Tangerin Banjar cultivars. Whereas in BF, none of the 13 samples deviated (Table 2). In Mandarin SoE, results of its DNA separation with ISSR (AG) $8 Y$ T marker indicated that all BF samples are same as their control, but not on BMB ones on (Figure 1).

Table 2 - Status of genetic deviations of five citrus cultivars of BF and BMB based on the results of DNA amplification using 10 ISSR markers and retrotransposon markers

\begin{tabular}{|c|c|c|c|}
\hline Cultivars & Total Samples & Kind of Samples & No (\%) off type) \\
\hline \multirow[t]{3}{*}{ M. Batu 55} & 1 & Mother plant & control \\
\hline & 1 & $\mathrm{BF}$ & $0(0)$ \\
\hline & 6 & BMB & $0(0)$ \\
\hline \multirow[t]{3}{*}{ M. SoE } & 1 & Mother plant & control \\
\hline & 3 & $\mathrm{BF}$ & $0(0)$ \\
\hline & 20 & BMB & $4(20)$ \\
\hline \multirow[t]{3}{*}{ M. Terigas } & 1 & Mother plant & kontrol \\
\hline & 2 & $\mathrm{BF}$ & $0(0)$ \\
\hline & 11 & BMB & $1(9.1)$ \\
\hline \multirow[t]{3}{*}{ T. Pontianak } & 1 & Mother plant & kontrol \\
\hline & 3 & BF & $0(0)$ \\
\hline & 16 & BMB & $0(0)$ \\
\hline \multirow[t]{3}{*}{ T. Banjar } & 1 & Mother plant & control \\
\hline & 4 & BF & 0 \\
\hline & 26 & BMB & $3(11.5)$ \\
\hline Total BF and BMB samples & 92 & & $8(8.7 \%)$ \\
\hline
\end{tabular}

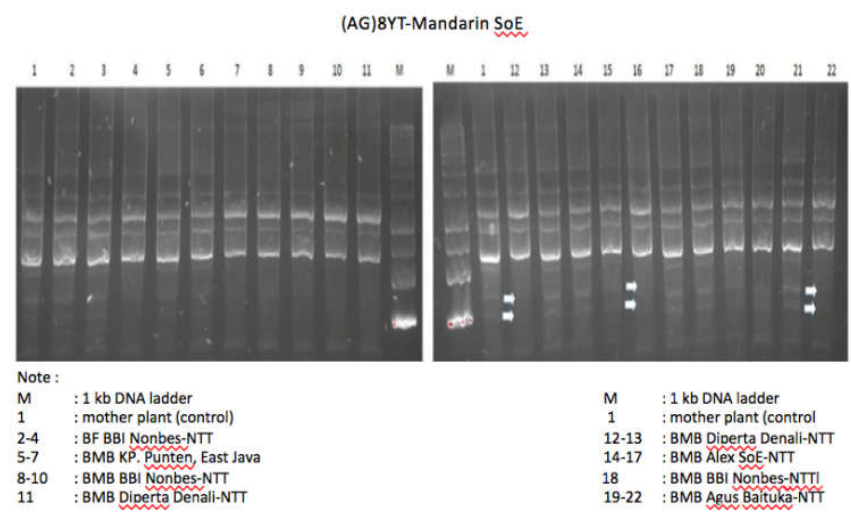

Figure 1 - Mandarin SoE DNA amplification with (AG)8YT marker of 22 samples based on ISSR method 
The degree of genetic deviation of BMB plants compared to their control were between 4.9 sd. $39.1 \%$, which the smallest and the biggest were in the Mandarin SoE and Tangerine Banjar, respectivelly (Table 2). Four samples, i.e. M.Terigas (Banyuwangi/ East Java) and 3 composite samples of T. Banjar (Kampar/Riau) had genetic deviations $>5 \%$ so they were not suitable to be used as parent plants (Table 3.; Figure 2.). According to Sharma et al. (2015), $95 \%$ value of genetic similarity among the grapefruit variants indicated a low level of variation. However, in spite of their low genetic base, they had a very wide phenotypic visible variation.

Table 1 - The degree of genetic deviation of BMB based on amplification result of 10 ISSR and retrotransposon markers

\begin{tabular}{llll}
\hline Cultivar & No. of samples & Origin of samples & Degree of deviation (\%) \\
\hline M. SoE & 11 & BMB Diperta Denali (NTT) & 4.9 \\
& 15 & BMB Alex-SoE (NTT) & 4.9 \\
& 21 & BMB Agus, Baituka (NTT) & 4.9 \\
& 22 & idem & 4.9 \\
\hline M. Terigas & 7 & BMB Banyuwangi & 10.3 \\
\hline T. Banjar & 16 & BMB Joneri - Kampar (Riau) & 5.6 \\
& 18 & BMB Baidarus - Kampar (Riau) & 36.1 \\
& 21 & idem & 11.1 \\
\hline
\end{tabular}
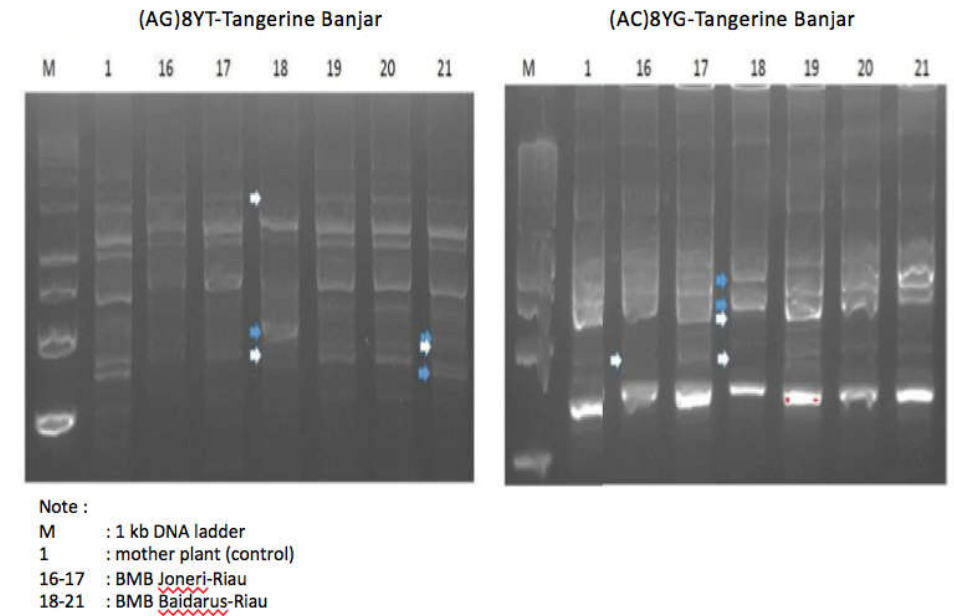

Figure 2 - Tangerine Banjar DNA amplification with (AG) 8YT and (AC)8YG markers of 6 samples based on ISSR method

Table 2 - Status of genetic deviations of five citrus cultivars of seedling and cultivated plants based on the results of DNA amplification using 10 ISSR markers and retrotransposon markers

\begin{tabular}{llll}
\hline Cultivars & Total Samples & Kind of Samples & No (\%) off type) \\
\hline M. Batu 55 & 1 & Mother plant & control \\
M. SoE & 15 & Cultivated plant & $2(13.3)$ \\
& 1 & Mother plant & control \\
M. Terigas & 8 & Seedling plant & $4(50)$ \\
& 1 & Mother plant & control \\
& 4 & Seedling plant & $1(25)$ \\
T. Pontianak & 9 & Cultivated plant & $2(22,2)$ \\
& 1 & Mother plant & control \\
& 11 & Seedling plant & $3(27.3)$ \\
\hline Total of seedling \& Cultivated plant samples & 19 & Cultivated plant & $1(5,3)$ \\
\hline
\end{tabular}

The percentage of off type would be higher in plants that have farther distance from their mother plant. Seedling and BMB takes the source materials from BMB and BF, respectively, while the BF itself is taken them from VF mother plant. From this scheme, the seedling plants had the furthest distance compared to the others. This appears in their 
genetic deviation status, from 158 samples, off type of the parent plants (BF and BMB) and commercial plants (seedling and produce plants) were $8(5.1 \%)$ and 13 samples $(8.2 \%)$, respectively. This result is consistent with the research of Uzun et al (2009), where genetic variation was found in 4-year-old lemon plants that were propagated vegetatively. The differences analyzed using RAPD and ISSR are thought to be caused by mutations (Sharma et al., 2015).

Table 3 - The degree of genetic deviation of seedling and cultivated plant based on amplification result of 10 ISSR and retrotransposon markers

\begin{tabular}{llll}
\hline Cultivar & No. of samples & Origin of samples & Degree of deviation (\%) \\
\hline M. Batu55 & 16 & Cultv. plants (Batu/East Java) & 5,6 \\
M. SoE & 18 & idem & 5,6 \\
& 25 & Seedling plants Diperta Denali (NTT) & 4,9 \\
& 27 & Seedling plants Alex SoE (NTT) & 7,3 \\
M. Terigas & 29 & idem & 7,3 \\
& 21 & Seedling plants Melki-SoE (NTT) & 3,7 \\
T. Pontianak & 22 & Seedling plants BBI Anjungan (Kalbar) & 23.1 \\
& 25 & Cultv. plants Citrus Center (Kalbar) & 12.8 \\
& 30 & idem & 10.3 \\
& 46 & Seedling plants Nongkojajar (East Java) & 2,7 \\
& & Seedling plants Awang Sambas (Kalbar) & 8,1 \\
& & Seedling plants Anjungan (Kalbar) & 2,7 \\
\end{tabular}

(AG)8YT-Mandarin Batu 55

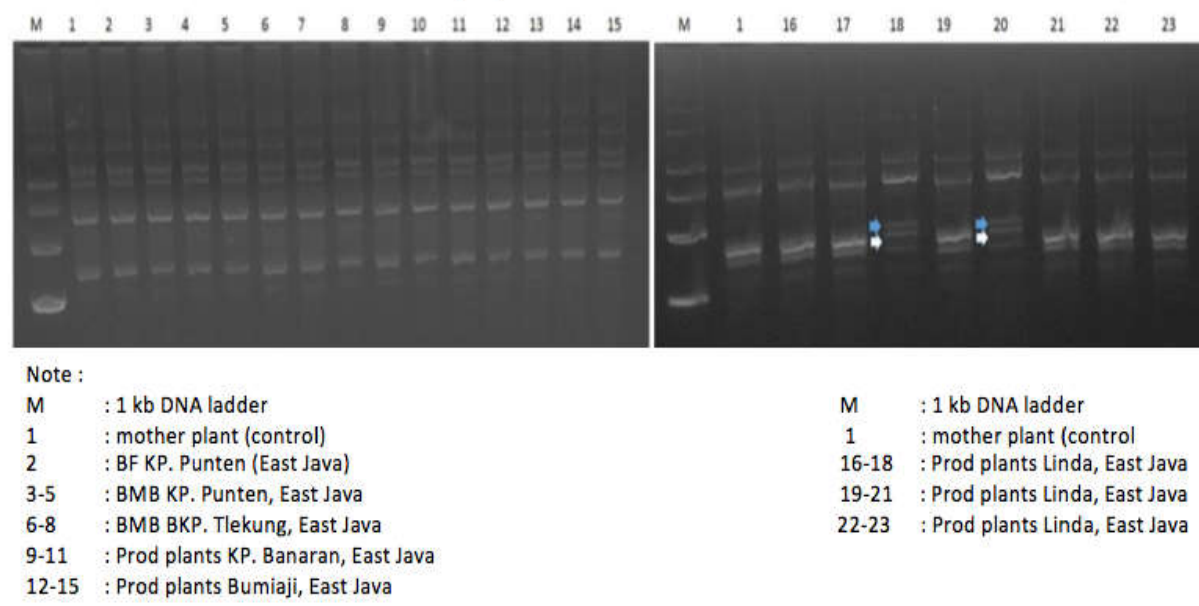

Figure 3 - Mandarin Batu 55 DNA amplification with (AG)8YT marker of 23 samples based on ISSR method

Mutations in plants can occur naturally, where mutant plants produced could have shifting in their properties, for example become sterile, which can be a limiting factor for fertilization and seed production (Bender et al, 2017). According to Nishiura (2018), the mutations in buds generally cause variations in low to high levels of plants or somatic tissues, so that the differences can be seen, measured and are consistent. In general, mutations in buds arise from changes in the character of genes (called "points" of mutations) produced by chromosomal aberrations or abnormal segregation, which causes loss, duplication, or rearrangement of genes (Qin et al., 2015).

\section{CONCLUSION}

This reseach indicated that genetic diversity occurs at the all level plants, but not BF. In $\mathrm{BMB}$, it was found to be very low $(5.1 \%)$, however in commercial ones (seedling and cultivated plants) were $8.2 \%$. The amount of its deviation was $4.9-36.1 \%$ and $2.7-23.1 \%$, respectively. 


\section{ACKNOWLEDGEMENTS}

We are thankful to IAARD for financial assistance for this work and all ISFRI Breeding Lab. Staffs for providing lab facilities.

\section{REFERENCES}

1. Alzohairy, A.M., Gábor Gyulai, G., Ramadan, M.F., Edris, S., Sabir, J.S.M., Jansen, R.K., Eissa, H.F. \& Bahieldin, A., 2014. Retrotransposon-based molecular markers for assessment of genomic diversity. Functional Plant Biology http://dx.doi.org/10.1071/FP13351

2. Bender, R.J., dos Santos, R.P., Guerra, D., Schwarz, S.F. \& Bender, S.S., 2017. 'URS Campestre' seedless orange: a new mutant with female sterility. Sci. Agric. 74 (5): $371-$ 377.

3. Bhattacharyya, P., Kumaria, S., Diengdoh, R. \& Tandon, P., 2014. Genetic stability and phytochemical analysis of the in vitro regenerated plants of Dendrobium nobile Lindl., an endangered medicinal orchid. Meta Gene 2: 489-504.

4. Biswas, M.K., Xu, Q. \& Deng, X., 2010. Utility of RAPD, ISSR, IRAP and REMAP markers for the genetic analysis of Citrus spp. Scientia Horticulturae 124:254-261.

5. Carra, A., Sajeva, M., Abbate, L., Siragusa, M., Sottile, F. \& Carimi, F., 2012. In vitro plant regeneration of caper (Capparis spinosa L.) from floral explants and genetic stability of regenerants. Plant Cell Tissue Organ Culture 109:373-381.

6. Devy, N.F, Hardiyanto, Dwiastuti, ME. 2015. Shoot Tip Grafting ang Indexing Technology. IAARD press. 80 pp.

7. Doyle, J.J. \& Doyle, J.L., 1990. Isolation of Plant DNA from Fresh Plant Tissue. Focus 12:13-15.

8. Harwanto \& Utomo, J.S., 2014. Review of Free-Virus-Tree Citrus Sources Support on Indonesia Citrus Agribusiness Development. National Fruit Seminar Paper, Bukit Tinggi, September $16^{\text {th }}$ 2014. $22 \mathrm{pp}$

9. Hirochika, H., 1995. Regulation of plant retrotransposons and their use for genome analysis. Gamma Field Symposium 34:77-91.

10. JinPing, X., Geng, C.L., Ming, X., Lin, V.H. \& Qi, Y.W., 2009. Identification of AFLP fragments linked to seedlessness in Ponkan mandarin (Citrus reticulata Blanco) and conversion to SCAR markers. Scientia Horticulturae 121:505-510.

11. Kalendar, R., Grob, T., Regina, M., Suomeni, A. \& Schulman, A., 1999. IRAP and REMAP two new retrotransposon-based DNA fingerprinting techniques. Theoretical and Applied Genetics 98:704-711. doi:10.1007/s0012 20051124

12. Kumar, S., Jena, S. N. \& Nai, N.K. 2010. ISSR polymorphism in Indian wild orange (Citrus indica Tanaka, Rutaceae) and related wild species in North-east India. Scientia Horticulturae 123:350-359

13. Marak, C.K \& M.A. Laskar, 2010. Analysis of phenetic relationship between Citrus indica Tanaka and a few commercially important citrus species by ISSR markers. Scientia Horticulturae 124:345-348

14. Martasari CK, Reflinur. (2012) Characterization of Indonesian 'Siam' cultivar (Citrus nobilis Lour.) by morphological and ISSR markers. ARPN J. Agric Biol Sci. 7: 830-835.

15. Munankarmi, N.N, Rana, N., Bhattarai, T., Shrestha, R.L., Joshi, B.K., Baral, B., \& Shrestha, S., 2018. Characterization of the Genetic Diversity of Acid Lime (Citrus aurantifolia (Christm.) Swingle) Cultivars of Eastern Nepal Using Inter-Simple Sequence Repeat Markers. Plants 7 (46); doi:10.3390/plants7020046

16. Nishiura, M. $2018 . \quad$ Mutation in $\quad$ Citrus. https://www.jircas.go.jp/en/file/7065/download?token=yu7xtajC. p. 10-14

17. Qin, Y., Xu, C. Ye, Z.. Teixeira Da Silva, J.E.A \& Hu, G., 2015. Seedless Mechanism of A New Citrus Cultivar 'Huami Wuhegonggan' (Citrus sinensis $\times$ C. reticulata). Pak. J. Bot., 47(6): 2369-2378. 
18. Saha, S., Sengupta, C., Ghosh, P., 2014. Molecular and phytochemical analyses to assess genetic stability in alginate-encapsulated microshoots of Ocimum gratissimum L. following in vitro storage. Nucleus 57:33-43.

19. Scarano, M.T., Abbate, L., Ferrante, S., Lucretti, S., Tusa, N., 2002a. ISSR-PCR technique: A useful method for characterizing new allotetraploid somatic hybrids of mandarin. Plant Cell Reports 20:1162-1166.

20. Scarano, M.T., Abbate, L., Ferrante, S., Lucretti, S., Tusa, N., 2002b. ISSR-PCR technique: a useful method for characterizing new allotetraploid somatic hybrids of mandarin. Plant Cell Report 20:1162 - 1166.

21. Sharma, N., Dubey, A.K., Srivastav, M., Singh, B.P., Singh, A.K. \& Singh, N.K., 2015. Assessment of genetic diversity in grapefruit (Citrus paradisi Macf) cultivars using physico- chemical parameters and microsatellite markers. AJCS 9 (1):62-68

22. Tautz, D. \& Renz, M., 1984. Simple sequences are ubiquitous repetitive components of eukaryotic genomes. Nucleic Acids Research 12:4127-4138.

23. Uzun, A, Gulsen, O., Kafa, G. \& Seday, U., 2009. Field performance and molecular iversification of lemon selections. Scientia Horticulturae 120:473-478

24. Weising, K., Nybom, H., Wolff, K. \& Kahl, G., 2005. DNA Fingerprinting in Plants: Principles, Methods and Applications. $2^{\text {nd }}$ Edition. Taylor \& Francis Group, 2005, 444 p. ISBN 0-8493-1488-7.

25. Zietkiewicz, E., Rafalski, A. \& Labuda, D., 1994. Genome fingerprinting by simple sequence repeat (SSR)-anchored polymerase chain reaction amplification. Genomics 20:176-183. 